\title{
DETERMINATION OF PHYSICAL PROPERTIES, MOISTURE ABSORPTION PROCESS AND AERODYNAMIC PROPERTIES OF GRAIN AND CLUSTER STRAW OF TWO WHEAT CULTIVARS
}

\author{
Mohammad Jafari¹, Gholam Reza Chegini², Javad Khazaei² \\ ${ }^{1}$ Lorestan Agricultural and Natural Resources Research and Education Center, AREEO, Khorramabad, Iran \\ ${ }^{2}$ Department of Agrotechnology, College of Abouraihan, University of Tehran, In Pakdasht, Tehran Province, \\ I. R. Iran
}

Link to this article: https://doi.org/10.11118/actaun202068050831

Received: 24. 5. 2019, Accepted: 19. 8. 2020

To cite this article: JAFARI MOHAMMAD, CHEGINI GHOLAM REZA, KHAZAEI JAVAD. 2020. Determination of Physical Properties, Moisture Absorption Process and Aerodynamic Properties of Grain and Cluster Straw of Two Wheat Cultivars. Acta Universitatis Agriculturae et Silviculturae Mendelianae Brunensis, 68(5): 831-840.

\begin{abstract}
In this study, physical properties of grain and cluster straw including geometric dimensions, moisture absorption and aerodynamic properties of two wheat cultivars were investigated. The effect of cultivar on width, thickness, geometric diameter, spheroid coefficient and mass density was significant at 1\% probability level whilst there were no significant effect on grain projected area, length and weight. Moisture absorption of the grains was rapid during the first 30-40 min and then turned to zero. The terminal velocity of wheat grain and straw in three shapes was measured by calculating the projected area in horizontal, lateral and perpendicular directions and then, the drag coefficient was obtained by the equilibrium of the gravity and drag forces at the terminal velocity. Results also showed that increasing moisture content resulted in an increase in the terminal velocity and a decrease in the drag coefficient. Results obtained in this study can be used in designing wheatcluster straw separation and processing.
\end{abstract}

Keywords: wheat grain, cluster straw, terminal velocity, drag coefficient

\section{INTRODUCTION}

The importance of determining physical properties of agricultural products is essential in the design of processing machines for post harvesting and food systems (Mohsenin, 1986). These properties are especially important in production of cereals such as wheat and barley in order to design of planting and harvesting machineries as well as transportation and processing (Baryeh, 2002). Kalkan and Kara (2011) have measured the length, width, thickness, mean geometric diameter, spheroid weight, 1000-seed weight and dynamic friction coefficient of five wheat cultivars as a function of moisture to optimize the different planting, harvesting and post harvesting processes, as well as to reduce the losses and increase the quality of wheat grains. For agricultural products, quality is defined by the degree of products' desirability which depends on physical, mechanical and chemical properties of products along with their storage time. The proper characteristics can be divided into two groups: apparent properties such as size, shape and external defects, and internal factors such as acidity, amount of herb sap, rigidity and internal fractures (Soltani et al., 2011).

One of the new methods for seed separating from impurities is the use of electrostatic separators. In these methods, the grains that cannot be separated 
by other common methods, are disassociated from other materials based on their electrical properties (Sarmadnia, 1997). Physical and aerodynamic characteristics of the particles are the factors that determine the performance of an electrostatic separator.

The particles' drag coefficient and terminal velocity are of the most important aerodynamic and hydrodynamic characteristics which influence gravity acceleration and fluid flow around them. Terminal velocity is an important factor in separating processes of seeds from straw material and Materials other than Grain (MOG) (Rabbani, 2002; Tabatabaeefar, 2003). This is important for determining the terminal velocity in the separation of grain particles and is therefore an effective factor in designing agricultural machines (Mohsenin, 1986).

The drag coefficient used to determine drag force is actually a factor that acts on a moving particle in the air and depends on the particle's properties such as mass, surface area, shape, and terminal velocity. The projected area and the drag coefficient in agricultural products, consistently change during pass through a separating system (Gursoy and Guzel, 2010). In most studies, the projected area of a particle is usually calculated based on its mean geometric diameter (Gorial and O'Callaghan, 1990; Khoshtaghaza and Mahdizadeh, 2006). Zewdu (2007) measured the grain drag coefficient and the straw resistance coefficient resulting from the multiplication of the drag coefficient and the projected area of the particle at the terminal velocity. In evaluating the effects of moisture on the terminal velocity of chopping forage using wind tunnel method, Hemmat et al. (2007) reported that the terminal velocity values were 1.7, 7.3 and $7.8 \mathrm{~m} / \mathrm{s}$ at three moisture content levels of 40-50, 50-60 and 60-70\%, respectively. They stated that only the shape of crushed forage particles has a significant effect on the terminal velocity.

A literature review reveals the lack of data on the wheat-related properties which are effective in design and development of grain separation machines. The aim of this study was to investigate physical properties of grain and cluster straw including geometric dimensions, moisture absorption and aerodynamic properties of two wheat cultivars.

\section{MATERIALS AND METHODS}

\section{Sample Preparation and Applying of Moisture Levels}

The clusters of Chamran 2 (Cham) and Mehregan (Mehr) wheat cultivars were obtained from the Research Farmland of Lorestan Agricultural Research Center and were then manually separated from the straw. Dry basis moisture content $\left(\mathrm{MC}_{\mathrm{db}}\right)$ of grain and straw were measured for each of cultivars in five replications using an oven. For increasing the $\mathrm{MC}_{\mathrm{d} . \mathrm{b} .}$ each grain sample was kept soaked separately for 5 to $25 \mathrm{~min}$ in distilled water at $25^{\circ} \mathrm{C}$ to study its effects on their properties (Khoshtaghaza and Mehdizadeh, 2006). Afterwards, apparent moisture was removed from the external surfaces and the samples were immediately weighed. Finally, they were placed in a hot oven at $104^{\circ} \mathrm{C}$ for $72 \mathrm{~h}$ (ASABE, 2006).

\section{Geometry Properties}

A total of 100 grains and 20 straw particles in four levels of chaff, rachis, cluster awn and stem were selected randomly from each cultivar. Their three-axis dimensions including length $\left(D_{L}\right)$, width $\left(D_{W}\right)$ and thickness $(t)$ were measured using a micrometer with $0.01 \mathrm{~mm}$ accuracy. The mean geometric diameter $\left(D_{g m}\right)$ and spherical coefficient $(\varphi)$ were calculated using the Eqs. (1) and (2), respectively (Mohsenin, 1986).

$D_{g m}=\left(D_{L} D_{W} t\right)^{1 / 3}$

$\varphi=\frac{D_{g m}}{D_{l}}$

According to the elliptic form of the wheat grains, their surface area $(S)$ was calculated using the Eq. (3) (Jia et al., 2008):

$S=2 \pi a^{2}(1+F G)$

where

$$
F=\frac{A}{(2 \sqrt{A-1})},
$$

$A=\frac{c^{2}}{a^{2}}$,

$G=\frac{\pi}{2}+\arcsin \left(\frac{A-2}{A}\right)$

where $a$ and $c$ are the lateral and longitudinal radius of the particles, respectively. Surface area of the chaff was calculated using Eq. (3). The surface area of the rachis-straw stems was calculated by considering the particle as a rectangular cube. Finally, the cluster awn was considered as a cylinder in its dimensions.

\section{Gravity Properties}

A number of 1,000 handcrafted and cleaned grains from each cultivar were separately collected and weighed using a digital scale (SATTORIUS, with 0.0001.g accuracy). In order to measure the apparent density of the wheat mass, the samples were poured into a cylindrical vessel with a volume $\left(V_{b}\right)$ of $0.1 \mathrm{~L}$. By weighing the total mass of the container, the mass weight $\left(m_{b}\right)$ was obtained by calculating the weight difference between the empty and filled container. According to Eq. (7), 
the volume density $\left(\rho_{b}\right)$ of the material (wheat and straw) was obtained by dividing the mass weight by the mass volume (Mohsenin, 1986).

$\rho_{b}=\frac{M}{V_{b}}$

To measure the particle density, 100 grains of wheat were first weighed $\left(M_{r}\right)$ and then poured into a calibrated burette containing $50 \mathrm{ml}$ toluene (Nalbandi et al., 2010; Unal et al., 2006). The volume of the sample $\left(V_{r}\right)$ was measured by rising the volume of the toluene. According to Eq. (8), the ratio of the mass $\left(M_{r}\right)$ to the volume of wheat $\left(V_{r}\right)$ was equal to the particle density $\left(\rho_{P}\right)$ (Mohsenin, 1986).

$\rho_{p}=\frac{M}{V_{r}}$

The density of straw particles was obtained by adding water to a certain mass of straw $\left(V_{\text {bulk }}\right)$ until its flotation. The difference in total volume and replaced water determined the volume of the straw particles (Mohsenin, 1986).

Porosity percentage $(e)$ is defined by dividing the volume of empty space between the particles to the total volume (Eq. 9).

$e=\left(1-\frac{V_{r}}{V_{b}}\right) \times 100 \approx\left(1-\frac{\rho_{p}}{\rho_{s}}\right) \times 100$

\section{Determination of Initial $M C_{\text {d.b. }}$ of Grain and Straw}

The $\mathrm{MC}_{\text {d.b. }}$ of the samples was measured in accordance with ASABE Standard (ASABE, 2006). Using Eq. (10) at $20^{\circ} \mathrm{C}$ :

$\% M C_{d . b .}=\frac{\left(w_{i}-w_{d}\right)}{w_{d}} \times 100$,

where $w_{i}$ is the weight after applying moisture (initial weight) and $w_{d}$ is the weight of the dried samples in the oven. The $\mathrm{MC}_{\text {d.b. }}$ for grains and straw were $10.6 \%$ and $8.3 \%$ in Cham, and $11.1 \%$ and $8.7 \%$ in Mehr cultivars. The weighed samples were then placed in immersion water for 1 to 135 min to study their moisture absorption behavior over time.

\section{Particle Surface and Aerodynamic Properties}

The separation of the wheat grains and straw in a harvesting process is based on their gravity, aerodynamic dimensions and atmospheric properties. These properties are used to separate seeds from other impurities (Nalbandi et al., 2010). The experimental method for determining the terminal velocity of agricultural products that do not have a geometric shape is more preferred than calculation method (Zewdu, 2007). For experimental measurement of the terminal velocity, the particles were placed at the center of the crosssection of a vertical wind tunnel. Increasing the airflow in this tunnel continued until the particles were suspended. The wind velocity was adjusted by varying the fan velocity through a frequency inverter and a diaphragm mounted to the system. At a time when the particle had the lowest spin, the wind velocity was measured by a hot wire with $0.1 \mathrm{~m} / \mathrm{s}$ accuracy. This experiment was carried out at two moisture content levels with four replications for each cultivar. The density of air was considered to be $1.206 \mathrm{~kg} / \mathrm{m}^{3}$ (Shahbazi et al., 2014).

When a suspended particle is at terminal velocity $\left(V_{t}\right)$, the particle weight $\left(F_{g}\right)$ is equal to the upward drag force $\left(F_{d}\right)$ and therefore, the velocity of the airflow in the wind tunnel equals to the suspended particle velocity. By placing the weight force instead of the drag force, the terminal velocity can be obtained using Eq. (11) (Mohsenin, 1986):

$V_{t}=\sqrt{\frac{2 M g\left(\rho_{p}-\rho_{f}\right)}{r_{p} \rho_{f} A_{p} C_{d}}}$,

where $A_{p}$ is the projected area of the particle $\left(\mathrm{m}^{2}\right)$, $C_{d}$ is the drag coefficient (dimensionless), $g$ is gravity acceleration $\left(\mathrm{m} / \mathrm{s}^{2}\right), M$ is particle mass $(\mathrm{kg}), V_{t}$ is terminal velocity $(\mathrm{m} / \mathrm{s}), \rho_{f}=1.29 \mathrm{~kg} / \mathrm{m}^{3}$ and $\rho_{p}$ is the air and particles' densities, respectively $\left(\mathrm{kg} / \mathrm{m}^{3}\right)$. $C_{d}$ can be calculated using Eq. (12).

$C_{d}=\frac{2 m g\left(\rho_{p}-\rho_{f}\right)}{\rho_{p} \rho_{f} A_{p} V_{t}^{2}}$

$A_{p}=\frac{\rho}{4} D_{l} D_{w}$
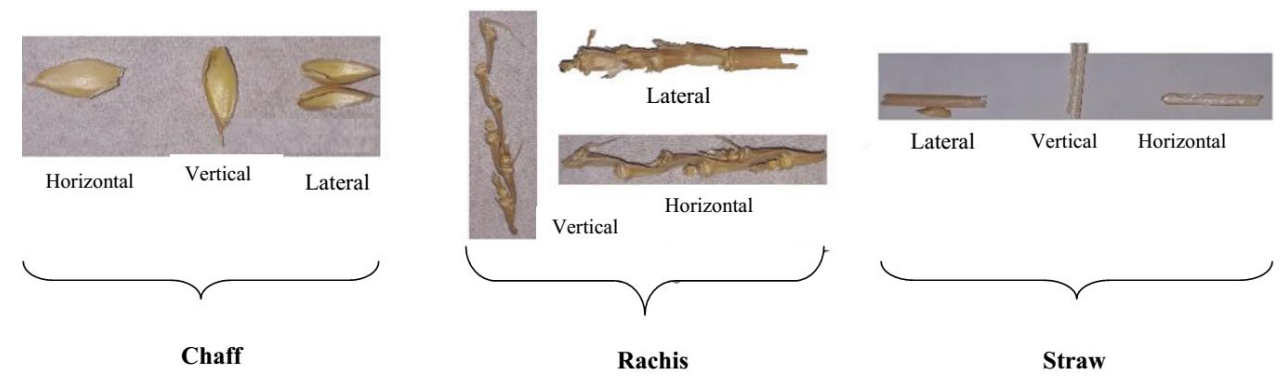

1: The shape and position of cluster straw in falling 
where $D_{l}$ and $D_{w}$ are the length and width of the particle (m), respectively (Fig. 1). As the projected areas of grains and straw may vary due to their irregular geometric shape and their position in airflow, the drag coefficient of grain and straw was calculated according to the projected area in their different positions.

\section{Statistical Analyses}

Means and standard deviations obtained in the experiments along with nonlinear regression models were calculated in Excel 2017 software environment. Analysis of variance and means comparison were performed using SAS (Ver. 9.1).

\section{RESULTS AND DISCUSSION}

\section{Geometric Dimensions}

Tab. I shows the mean and standard deviation of geometric dimensions of the wheat grain and straw. According to the results, the length, width, thickness, and mean geometric diameter of Cham cultivar were 6.6, 2.1, 3.6, and $4.0 \mathrm{~mm}$, respectively. For Mehr cultivar, these parameters were 6.6, 2.5, 3.3 , and $3.8 \mathrm{~mm}$, respectively. These values for MOG including straw and rachis and cluster awn had more variations in the range of less than $1 \mathrm{~mm}$ to $30 \mathrm{~mm}$. The sphericity coefficient of grain, chaff and straw for Cham and Mehr cultivars were 61, 19.8, 32.1, 57.5, 28.3 and 29.1\%, respectively, and for rachis and cluster awn in both cultivars were measured approximately 21 and 9\%, respectively. The total volume and surface area were $45.5 \mathrm{~mm}^{3}$ and $63.9 \mathrm{~mm}^{2}$, in Cham cultivar and $37.3 \mathrm{~mm}^{3}$ and $59.0 \mathrm{~mm}^{2}$ in Mehr cultivar. The apparent density for grains and straw were 852.3 and $55.1 \mathrm{~kg} / \mathrm{m}^{3}$ in Cham, and 858.4 and $60.66 \mathrm{~kg} / \mathrm{m}^{3}$ in Mehr cultivar. The particle density was 1290 and $97 \mathrm{~kg} / \mathrm{m}^{3}$ in Cham, and 1200 and $110 \mathrm{~kg} / \mathrm{m}^{3}$ in Mehr cultivar. The porosity of these particles was 25 and $40 \%$ in Cham, and 22 and 39\% in Mehr. The 1000-grain weight of Cham and Mehr cultivars were measured 49.7 and 48.9 g, respectively (Tab. II).

\section{Moisture Contents}

The average values of moisture contents for the two wheat cultivars at different moisture saturation periods are shown in Tab. III. The $\mathrm{MC}_{\mathrm{db}}$. was calculated at seven levels of moisture saturation times equal to 1, 15, 45, 75, 105, 120 and $135 \mathrm{~min}$ (Fig. 2). Regression models for moisture absorption versus time in wheat grains and straw of the two cultivars are shown in this figure.

In these equations, there is an acceptable correlation between the water absorption of grain and straw mass and their soaking period. According to Fig. 2, the increase in moisture content reduced

I: Mean of dimensions, geometric diameter and spherical coefficient of grain and straw of wheat cultivars in common moisture. Data for length, width, thickness, equivalent diameter, and spherical coefficient are shown as mean values \pm standard deviations.

\begin{tabular}{lccccccc}
\hline \multicolumn{1}{c}{ Particles } & $\begin{array}{c}\text { Length } \\
(\mathrm{mm})\end{array}$ & $\begin{array}{c}\text { Width } \\
(\mathrm{mm})\end{array}$ & $\begin{array}{c}\text { Thickness } \\
(\mathrm{mm})\end{array}$ & $\begin{array}{c}\text { Mean geometric } \\
\text { diameter } \\
(\mathrm{mm})\end{array}$ & $\begin{array}{c}\text { Spherical } \\
\text { coefficient } \\
(\%)\end{array}$ & $\begin{array}{c}\text { Volume } \\
\left(\mathrm{mm}^{3}\right)\end{array}$ & $\begin{array}{c}\text { Surface area } \\
\left(\mathrm{mm}^{2}\right)\end{array}$ \\
\hline Cham grain & $6.61 \pm 0.5$ & $2.1 \pm .3$ & $3.55 \pm 0.2$ & $4.04 \pm 0.3$ & $61 \pm 1.6$ & 45.5 & 63.9 \\
\hline Mehr grain & $6.56 \pm 0.6$ & $2.48 \pm 0.3$ & $3.29 \pm 0.3$ & $3.77 \pm 0.3$ & $57.45 \pm 0.9$ & 37.3 & 59.0 \\
\hline Cham chaff & $9.1 \pm 0.3$ & $3.02 \pm 0.1$ & $0.87 \pm 0.2$ & $4.16 \pm 0.6$ & $19.84 \pm 11.5$ & 31.2 & 68.21 \\
Mehr chaff & $8.6 \pm 0.7$ & $3.12 \pm 0.3$ & $0.87 \pm 0.2$ & $3.84 \pm 0.7$ & $28.26 \pm 10.7$ & 28.4 & 63.5 \\
\hline Cham rachis & $21.6 \pm 3.7$ & $3.36 \pm 2.3$ & $1.42 \pm 0.2$ & $4.69 \pm 1.0$ & $21.7 \pm 8.2$ & 101.0 & 142.2 \\
Mehr rachis & $21.3 \pm 2.8$ & $3.33 \pm 1.6$ & $1.35 \pm 0.2$ & $4.54 \pm 1.3$ & $21.13 \pm 7.8$ & 93.3 & 139.8 \\
\hline Cham awn & $29.1 \pm 4.2$ & $0.75 \pm 0.4$ & $0.85 \pm .02$ & $2.64 \pm 1.9$ & $9.07 \pm 6.9$ & 18.9 & 73.3 \\
Mehr awn & $24.7 \pm 3.6$ & $0.73 \pm 0.3$ & $0.72 \pm 0.1$ & $2.38 \pm 1.5$ & $9.63 \pm 10.1$ & 13.3 & 56.1 \\
\hline Cham straw & $12.6 \pm 2.3$ & $4.46 \pm 1.8$ & $1.18 \pm 0.2$ & $4.04 \pm 1.0$ & $32.06 \pm 15.4$ & 64.0 & 918 \\
Mehr straw & $14.6 \pm 2.8$ & $4.28 \pm 1.2$ & $1.23 \pm 0.2$ & $4.24 \pm 1.2$ & $29.06 \pm 14.7$ & 73.7 & 104.6 \\
\hline
\end{tabular}

II: Apparent density, particle density, porosity and 1000-grain weight of grain and straw of wheat cultivars. Data are shown as mean values \pm standard deviations.

\begin{tabular}{lcccc}
\hline \multicolumn{1}{r}{ Particle } & Apparent density $\left(\mathrm{kg} / \mathrm{m}^{3}\right)$ & Particle density $\left(\mathrm{kg} / \mathrm{m}^{3}\right)$ & Porosity & 1000-grain weight $(\mathrm{g})$ \\
\hline Cham grain & $852.3 \pm 1.3$ & $1290.4 \pm 42.2$ & $25.05 \pm 0.02$ & $49.7 \pm 0.1$ \\
Mehr grain & $858.4 \pm 1.6$ & $1200.5 \pm 22.4$ & $22.09 \pm 0.06$ & $48.9 \pm 0.1$ \\
\hline Cham straw & $55.1 \pm 9.3$ & $97.2 \pm 10.5$ & $40.02 \pm 0.20$ & - \\
Mehr straw & $60.67 \pm 9.3$ & $101.1 \pm 10.6$ & $39.22 \pm 0.30$ & - \\
\hline
\end{tabular}


III: The moisture absorption values of the particles with their establishment in saturated state at different times

\begin{tabular}{cccccc}
\hline \multirow{2}{*}{$\begin{array}{c}\text { Saturation time } \\
(\mathrm{s})\end{array}$} & \multicolumn{3}{c}{ Moisture content (\%) } \\
\cline { 2 - 5 } & \multicolumn{2}{c}{ Cham } & \multicolumn{3}{c}{ Mehr } \\
\cline { 2 - 5 } \cline { 5 - 6 } & Grain & Straw & & Grain & Straw \\
\hline 0 & 10.6 & 7.2 & 11.1 & 7.7 \\
\hline 1 & 12.2 & 19.1 & 13.2 & 18.8 \\
\hline 15 & 13.4 & 35.2 & 20.8 & 35.1 \\
\hline 45 & 25.7 & 40.8 & 40.8 & 41.6 \\
75 & 31.0 & 42.5 & 45.2 & 45.1 \\
\hline 105 & 35.7 & 44.3 & 49.7 & 48.1 \\
\hline 120 & 36.1 & 46.1 & 51.9 & 51.3 \\
\hline 135 & 34.2 & 47.6 & 51.9 & 53.3 \\
\hline
\end{tabular}

over time and after a certain time, the moisture absorption was stopped. The maximum grain moisture absorption for Cham and Mehr cultivars was 36\% and 52\%, respectively after $120 \mathrm{~min}$. Yildirim et al. (2011) obtained similar results in terms of $\mathrm{MC}_{\mathrm{db}}$ change of chickpea during soaking with ultrasound method in different temperatures from 20 to $97^{\circ} \mathrm{C}$.

\section{Aerodynamic Properties}

The average projected area and terminal velocity measured for grains and straw particles in the two cultivars are shown in Tab. IV. The projected area decreased in both grain and straw, when their position changed from horizontal to lateral. Similar results were reported by Gürsoy and Güzel (2010) in estimating the surface area of wheat, barley, pea and lentil.

According to Tab. IV, it was found that in spite of higher drag coefficients, the terminal velocity in the vertical position was lower than the horizontal and lateral due to its low projected area. However, in the case of horizontal and lateral, the terminal velocity difference was not significant. By changing the $\mathrm{MC}_{\mathrm{db}}$ of grains and straw particles from 14 to $20 \%$, terminal velocity and consequently, the drag coefficient decreased. The reason for this phenomena may be due to the increasing of the particle weight without increasing the projected area during falling.

Gupta et al. (2007) showed that the average terminal velocity increased from 2.93 to $3.28 \mathrm{~m} / \mathrm{s}$ by increasing $\mathrm{MC}_{\text {d.b. }}$ from 6 to 14\% for sunflower seeds. Rajabipour et al. (2006) reported similar trends with a linear equation and $R^{2}$ of $0.95,0.91$ and 0.92 for Mahdavi, Marvdasht and Pishtaz wheat cultivars, respectively. The maximum terminal velocity was obtained $6.9 \mathrm{~m} / \mathrm{s}$ for Mahdavi and $1.6 \mathrm{~m} / \mathrm{s}$ for Marvdasht cultivars (Rajabipour et al., 2006). Khoshtaghaza and Mehdizadeh (2006) reported an increase in the terminal velocity from 2.35 to $4.85 \mathrm{~m} / \mathrm{s}$ in length changes of wheat straw from 10 to $100 \mathrm{~mm}$. In their study, the changes in terminal velocity and the resistance coefficient depended on the node place in straw and its length (Khoshtaghaza and Mehdizadeh, 2006).

As shown in Fig. III, there was no significant difference in terminal velocity and the drag coefficient of grains in different moisture contents, especially in horizontal and lateral sections, but this difference was obvious between grains and rachis particles. The terminal velocity in grains was higher and the drag coefficient was lower than rachis particles. There was also a difference between the straw in the form of rachis and other forms of straw. Nalbandi et al. (2010) reported a significant difference between the terminal velocity of wheat grains and Turgenia latifolia seeds. In their study, the effect of $\mathrm{MC}_{\mathrm{db}}$ of grains on this property was significant. The terminal velocity of wheat grains at both $\mathrm{A}$ and $\mathrm{B}$ grades increased from 9.25 to $9.59 \mathrm{~m} / \mathrm{s}$ and from 8.353 to $8.757 \mathrm{~m} / \mathrm{s}$, respectively, as the $\mathrm{MC}_{\text {w.b }}$ increased from 7 to $20.8 \%$. $\mathrm{MC}_{\text {d.b. }}$ did not significantly affect the terminal velocity of Turgenia latifolia seeds at both cases. They also showed that

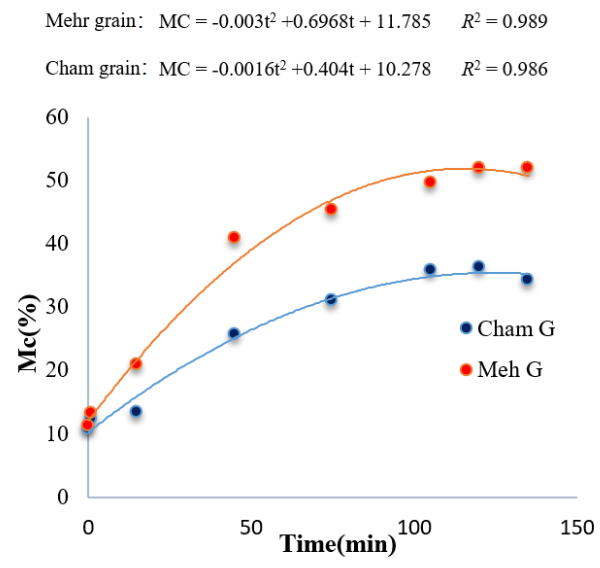

(a)

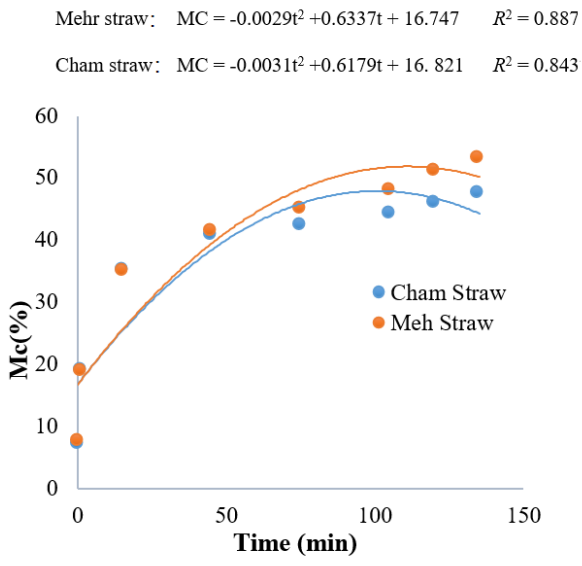

(b)

2: Moisture content in wheat (a) grain and (b) straw in two cultivars 
IV: Wheat grain and straw project area of Cham and Mehr cultivars in two levels of moisture contains

\begin{tabular}{|c|c|c|c|c|c|c|c|c|c|c|}
\hline & \multirow{2}{*}{ Section } & \multirow{2}{*}{$\begin{array}{l}\mathrm{MC}_{\mathrm{db}} \\
(\%)\end{array}$} & \multirow{2}{*}{$\begin{array}{l}\text { Cham } \\
\text { Grain }\end{array}$} & \multirow{2}{*}{$\begin{array}{l}\text { Mehr } \\
\text { Grain }\end{array}$} & \multicolumn{3}{|c|}{ Cham cluster straw } & \multicolumn{3}{|c|}{ Mehr cluster straw } \\
\hline & & & & & Chaff & Rachis & Straw & Chaff & Rachis & Straw \\
\hline \multirow{6}{*}{$\begin{array}{l}\text { Projected area } \\
\left(\mathrm{mm}^{2}\right)\end{array}$} & \multirow{2}{*}{ Horizontal } & 14 & 18.43 & 16.95 & 3.29 & 44.25 & 50.39 & 3.14 & 43.98 & 49.48 \\
\hline & & 20 & 18.87 & 17.49 & 3.21 & 45.1 & 53.19 & 3.09 & 44.81 & 51.19 \\
\hline & \multirow{2}{*}{ Lateral } & 14 & 14.53 & 12.77 & 13.13 & 11.23 & 33.56 & 12.56 & 11.00 & 32.98 \\
\hline & & 20 & 16.58 & 12.96 & 13.48 & 12.4 & 35.97 & 12.89 & 12.12 & 35.02 \\
\hline & \multirow{2}{*}{ Vertical } & 14 & 7.81 & 6.41 & 0.71 & 3.78 & 5.23 & 0.78 & 3.15 & 4.71 \\
\hline & & 20 & 9.15 & 6.73 & 0.86 & 3.59 & 5.37 & 0.82 & 3.03 & 4.8 \\
\hline \multirow{6}{*}{$\begin{array}{l}\text { Terminal velocity } \\
\left(\mathrm{ms}^{-1}\right)\end{array}$} & \multirow{2}{*}{ Horizontal } & 14 & 7.28 & 7.3 & 0.35 & 2.21 & 0.6 & 0.35 & 2.45 & 0.6 \\
\hline & & 20 & 7.75 & 7.81 & 0.41 & 2.35 & 0.69 & 0.42 & 2.59 & 0.71 \\
\hline & \multirow{2}{*}{ Lateral } & 14 & 7.38 & 7.42 & 0.37 & 2.36 & 0.80 & 0.38 & 2.55 & 0.8 \\
\hline & & 20 & 7.68 & 7.73 & 0.46 & 2.52 & 0.83 & 0.48 & 2.72 & 0.85 \\
\hline & \multirow{2}{*}{ Vertical } & 14 & 8.21 & 8.34 & 0.49 & 3.63 & 1.2 & 0.52 & 3.89 & 1.8 \\
\hline & & 20 & 8.69 & 8.86 & 0.6 & 3.98 & 1.39 & 0.64 & 4.21 & 1.93 \\
\hline \multirow{6}{*}{ Drag coefficient } & \multirow{2}{*}{ Horizontal } & 14 & 0.083 & 0.087 & 8.39 & 0.5 & 1.03 & 8.4 & 0.5 & 1.03 \\
\hline & & 20 & 0.071 & 0.074 & 5.7 & 0.42 & 0.72 & 5.7 & 0.41 & 0.72 \\
\hline & \multirow{2}{*}{ Lateral } & 14 & 0.102 & 0.112 & 1.78 & 0.68 & 2.32 & 1.78 & 0.69 & 2.32 \\
\hline & & 20 & 0.083 & 0.102 & 1.04 & 0.55 & 1.81 & 1.06 & 0.55 & 1.82 \\
\hline & \multirow{2}{*}{ Vertical } & 14 & 0.154 & 0.178 & 15.22 & 2.07 & 1.6 & 15.2 & 2.07 & 1.69 \\
\hline & & 20 & 0.117 & 0.15 & 9.2 & 1.55 & 1.24 & 9.2 & 1.55 & 1.22 \\
\hline
\end{tabular}

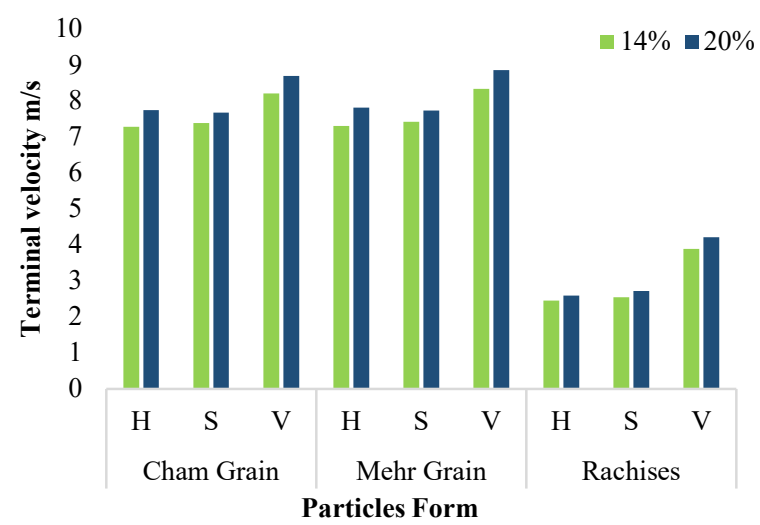

(a)

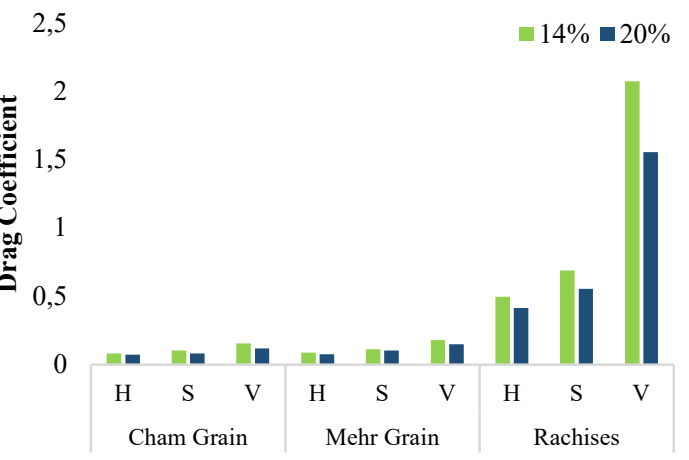

Particles Form

(b)

3: Comparative of wheat grain and rachis (a) terminal velocity and (b) drag coefficient in two cultivars

there was a significant difference between the drag coefficients of wheat and Turgenia latifolia grains. Reduction in drag coefficients of wheat grains was between $1.8 \%$ to $2.8 \%$, and in Turgenia latifolia grains, it was between 11.8 to $12.7 \%$ as the $\mathrm{MC}_{\text {w.b. }}$ decreased from 7 to 20.08\% (Nalbandi et al., 2010). In another research, the terminal velocity of millet grain varied from 2.75 to $4.63 \mathrm{~m} / \mathrm{s}$ due to an increase in $\mathrm{MC}_{\text {d.b. }}$ from 5 to 22.5\% (Baryeh, 2002). Zewdu (2007) measured the terminal velocity of Tef grains. He reported that it increases linearly from 3.08 to $3.96 \mathrm{~m} / \mathrm{s}$ by increasing $\mathrm{MC}_{\text {w.b. }}$ from 6.5 to $30 \%$. Similar results were reported for African yam bean (Irtwange and Ugbeka, 2003), coffee cherries and beans (Júnior et al., 2007) and cotton seeds (Tabakand Wolf, 1998).

\section{Results of Statistical Analyses}

\section{Physical Properties of Grains}

The analysis of variance for physical characteristics of the two wheat cultivars is shown in Tab. V at $\mathrm{MC}_{\mathrm{db}}$. from 14 and 20\%. In this analysis, it was determined that the effect of cultivar was significant at $1 \%$ probability level on diameter (width), thickness, geometric diameter, sphericity coefficient and 
$\mathrm{V}$ : Analysis of variance of cultivar and $M C_{d . b .}$ and their interactions on physical properties of wheat grain

\begin{tabular}{lccccccccc}
\hline & \multicolumn{7}{c}{ Mean of squares } \\
\cline { 2 - 10 } Sources of variations & DF & $\begin{array}{c}\text { Projected } \\
\text { area (A) }\end{array}$ & $\begin{array}{c}\text { Length } \\
\left(D_{L}\right)\end{array}$ & $\begin{array}{c}\text { Width } \\
\left(D_{W}\right)\end{array}$ & $\begin{array}{c}\text { Thickness } \\
(t)\end{array}$ & $\begin{array}{c}\text { Weight } \\
\left(w_{g}\right)\end{array}$ & $\begin{array}{c}\text { Geometric } \\
\text { diameter } \\
\left(D_{g m}\right)\end{array}$ & $\begin{array}{c}\text { Sphericity } \\
(\varphi)\end{array}$ & $\begin{array}{c}\text { Density } \\
(\rho)\end{array}$ \\
\hline Cultivar & 1 & $23.61^{\text {ns }}$ & $0.067^{\text {ns }}$ & $1.12^{* *}$ & $0.71^{* *}$ & $227.6^{\text {ns }}$ & $0.78^{* *}$ & $0.027^{* *}$ & $246288.9^{* *}$ \\
MCdb & 1 & $2.12^{\text {ns }}$ & $0.00004^{\text {ns }}$ & $0.05^{\text {ns }}$ & $0.077^{\text {ns }}$ & $78.9^{\text {ns }}$ & $0.046^{\text {ns }}$ & $0.001^{*}$ & $838.49^{\text {ns }}$ \\
Cultivar $\times \mathrm{MC}_{\text {db. }}$ & 1 & $0.14^{\text {ns }}$ & $0.0073^{\text {ns }}$ & $0.002^{\text {ns }}$ & $0.0006^{\text {ns }}$ & $0.12^{\text {ns }}$ & $0.002^{\text {ns }}$ & $0.0^{\text {ns }}$ & $1946022^{\text {ns }}$ \\
\hline Error & 36 & 7.34 & 0.29 & 0.079 & 0.085 & 136.96 & 0.103 & 0.0002 & 4676.08 \\
\hline
\end{tabular}

ns = non-significant, ${ }^{*}=\mathrm{P} \leq 0.05 ; * *=\mathrm{P} \leq 0.01$

VI: Mean comparison of the effects of cultivar and $M C_{d b}$ and their interactions on physical properties of wheat grain

\begin{tabular}{|c|c|c|c|c|c|c|c|c|}
\hline Physical properties of wheat grain & \multicolumn{2}{|c|}{ Cultivar } & \multicolumn{2}{|c|}{ Moisture content } & \multicolumn{4}{|c|}{ Cultivar $\times$ moisture content } \\
\hline Projected area $\left(\mathrm{mm}^{2}\right)$ & $18.8^{\mathrm{a}}$ & $17.2^{\mathrm{a}}$ & $17.8^{\mathrm{a}}$ & $18.3^{\mathrm{a}}$ & $18.5^{\mathrm{a}}$ & $19.1^{\mathrm{a}}$ & $17.1^{\mathrm{a}}$ & $17.4^{\mathrm{a}}$ \\
\hline Length (mm) & $6.6^{\mathrm{a}}$ & $6.6^{\mathrm{a}}$ & $6.6^{\mathrm{a}}$ & $6.6^{\mathrm{a}}$ & $6.6^{\mathrm{a}}$ & $6.6^{\mathrm{a}}$ & $6.5^{\mathrm{a}}$ & $6.5^{\mathrm{a}}$ \\
\hline Thickness (mm) & $3.6^{\mathrm{a}}$ & $3.3^{b}$ & $3.4^{\mathrm{a}}$ & $3.5^{\mathrm{a}}$ & $3.6^{\mathrm{ab}}$ & $3.6^{\mathrm{a}}$ & $3.3^{b}$ & $3.4^{\mathrm{ab}}$ \\
\hline Weight (mg) & $51.2^{\mathrm{a}}$ & $46.4^{\mathrm{a}}$ & $47.4^{\mathrm{a}}$ & $50.2^{\mathrm{a}}$ & $49.7^{a}$ & $52.6^{a}$ & $45.1^{\mathrm{a}}$ & $47.8^{\mathrm{a}}$ \\
\hline Geometric diameter (mm) & $4.6^{\mathrm{a}}$ & $3.8^{\mathrm{b}}$ & $3.9^{a}$ & $4.0^{\mathrm{a}}$ & $4.0^{\mathrm{ab}}$ & $4.1^{\mathrm{a}}$ & $3.8^{b}$ & $3.8^{\mathrm{ab}}$ \\
\hline Sphericity (\%) & $61.5^{\mathrm{a}}$ & $58.0^{b}$ & $59.2^{\mathrm{b}}$ & $60.2^{\mathrm{a}}$ & $61.0^{\mathrm{a}}$ & $62.0^{a}$ & $57.4^{\mathrm{b}}$ & $57.5^{b}$ \\
\hline
\end{tabular}

Means with the same letter in each column are not significantly different according to Duncan Multiple Range Test

density of grain. There were no significant differences between two cultivars in projected area, length and grain weight. The effect of $\mathrm{MC}_{\mathrm{d} . \mathrm{b}}$ on the spherical coefficient was significant at 5\% probability level. Interaction effect of cultivar and $\mathrm{MC}_{\text {d.b. }}$ was not significant on the grain physical characteristics.

According to Tab. VI, the means comparison of the projected area for the two cultivars and two levels of $\mathrm{MC}_{\text {d.b. }}$ did not show any significant difference. The highest projected area of wheat grain was $19.1 \mathrm{~mm}^{2}$ in Cham cultivar in $\mathrm{MC}_{\text {w.b. }}$ equal to $20 \%$ and its lowest value was $17.1 \mathrm{~mm}^{2}$ in Mehr cultivar at the $\mathrm{MC}_{\text {d.b. }}$ equal to $14 \%$, respectively. The length of the grains in both cultivars and the two levels of moisture content did not differ significantly.

The width of grains of both cultivars was in two statistical groups. Cham cultivar with $2.9 \mathrm{~mm}$ width at 20\% MCdb had the highest amount and Mehr cultivar grain with a $2.5 \mathrm{~mm}$ width in $14 \% \mathrm{MCdb}$ had the lowest amount. The grain thickness of the both cultivars was also in two groups. The highest thickness was $3.6 \mathrm{~mm}$ for Cham cultivar grains at $20 \% \mathrm{MC}_{\mathrm{db}}$ whilst the lowest was $3.3 \mathrm{~mm}$ for the Mehr cultivar at $14 \% \mathrm{MC}_{\text {d.b. }}$ Grain weight in both cultivars and MCdb was at one statistical level. The highest and lowest amounts of grain weight were in the Cham cultivar at $20 \% \mathrm{MC}_{\text {d.b. }}$ and Mehr cultivar at
$14 \% \mathrm{MC}_{\mathrm{d.b}}$, equal to 52.6 and $45.1 \mathrm{mg}$, respectively. Grain sphericity of Cham and Mehr cultivars was $61.5 \%$ and $58 \%$, respectively. The average density of grains in Cham cultivar was $1423 \mathrm{~kg} / \mathrm{m}$ and in Mehr cultivar was $1581 \mathrm{~kg} / \mathrm{m}$.

\section{Physical Properties of Straw}

The results of analysis of variance of physical properties of wheat straw in three shape of chaff, straw and cluster rachis for Cham and Mehr cultivars are shown in Tab. VII. The effect of cultivar was significant at 1\% probability level on length, width and mean geometric diameter but was not significant on thickness, weight and spherical coefficient of straw particles. The effects of the shape were significant on all characteristics except spherical coefficients at $1 \%$ probability level. The interaction of cultivar and shape was significant on the thickness and mean geometric diameter at 1\% probability level and on the width at 5\% probability level.

The means comparison of the straw dimensions in different cultivars and shapes is presented in Tab. VII. In this comparison, the amount of straw length, width and geometric diameter of Mehr cultivar were more than of Cham cultivar, and the value of thickness, weight and spherical coefficient of Mehr cultivar were lower. The maximum length, 
VII: Analysis of variance of the effect of cultivar, shape and their interaction on physical and geometric properties of wheat straw particles

\begin{tabular}{|c|c|c|c|c|c|c|c|}
\hline \multirow[b]{2}{*}{ Sources of variations } & \multirow[b]{2}{*}{ DF } & \multicolumn{6}{|c|}{ Mean of squares } \\
\hline & & Length $\left(D_{L}\right)$ & Width $\left(D_{W}\right)$ & Thickness $(t)$ & Weight $\left(w_{g}\right)$ & $\begin{array}{c}\text { Geometric } \\
\text { diameter }\left(D_{g m}\right)\end{array}$ & $\begin{array}{c}\text { Sphericity } \\
(\varphi)\end{array}$ \\
\hline Cultivar & 1 & $272.7^{* *}$ & $11.0^{* *}$ & $0.7^{\mathrm{ns}}$ & $81.4^{\mathrm{ns}}$ & $4.3^{* *}$ & $0.01^{\mathrm{ns}}$ \\
\hline Shape & 2 & $323.8^{* *}$ & $8.8^{* *}$ & $4.1^{* *}$ & $1075.2^{* *}$ & $5.9^{* *}$ & $0.03^{\mathrm{ns}}$ \\
\hline Cultivar $\times$ shape & 2 & $22.2^{\text {ns }}$ & $3.3^{*}$ & $1.4^{* *}$ & $13.9^{\text {ns }}$ & $6.3^{* *}$ & $0.02^{\text {ns }}$ \\
\hline Error & 24 & 23.4 & 0.7 & 0.2 & 80.9 & 0.4 & 0.01 \\
\hline
\end{tabular}

ns = non-significant, ${ }^{*}=\mathrm{P} \leq 0.05 ; * *=\mathrm{P} \leq 0.01$

VIII: Comparison of the cultivar, shape and their interactions effects on the physical properties

\begin{tabular}{|c|c|c|c|c|c|c|c|c|c|c|c|}
\hline \multirow{3}{*}{$\begin{array}{l}\text { Straw physical } \\
\text { properties }\end{array}$} & \multicolumn{2}{|c|}{ Cultivar } & \multicolumn{3}{|c|}{ Straw shape } & \multicolumn{6}{|c|}{ Cultivar $\times \mathrm{MC}_{\mathrm{db}}$. } \\
\hline & \multirow{2}{*}{ Cham } & \multirow{2}{*}{ Mehr } & \multirow{2}{*}{ Chaff } & \multirow{2}{*}{ Straw } & \multirow{2}{*}{ Rachis } & \multicolumn{3}{|c|}{ Cham } & \multicolumn{3}{|c|}{ Mehr } \\
\hline & & & & & & Chaff & Straw & Rachis & Chaff & Straw & Rachis \\
\hline Length (mm) & $12.5^{b}$ & $18.5^{\mathrm{a}}$ & $9.1^{b}$ & $17.4^{\mathrm{a}}$ & $20.1^{\mathrm{a}}$ & $7.1^{c}$ & $12.7^{\mathrm{b}}$ & $17.7^{\mathrm{a}}$ & $11.1^{\mathrm{b}}$ & $22.1^{\mathrm{a}}$ & $22.4^{\mathrm{a}}$ \\
\hline Width (mm) & $2.5^{\mathrm{b}}$ & $3.7^{\mathrm{a}}$ & $3.9^{\mathrm{a}}$ & $2.1^{\mathrm{b}}$ & $3.2^{\mathrm{a}}$ & $2.7^{\mathrm{bc}}$ & $1.9^{c}$ & $2.8^{\mathrm{b}}$ & $5.2^{\mathrm{a}}$ & $2.3^{\mathrm{bc}}$ & $3.5^{b}$ \\
\hline Thickness (mm) & $1.3^{\mathrm{a}}$ & $1.0^{\mathrm{a}}$ & $0.7^{\mathrm{b}}$ & $0.9^{b}$ & $1.9^{\mathrm{a}}$ & $1.1^{\mathrm{bc}}$ & $1.2^{\mathrm{bc}}$ & $1.6^{\mathrm{ab}}$ & $0.3^{\mathrm{d}}$ & $0.6^{\mathrm{dc}}$ & $2.2^{\mathrm{a}}$ \\
\hline Weight (mg) & $19.2^{\mathrm{a}}$ & $15.9^{\mathrm{a}}$ & $8.2^{\mathrm{b}}$ & $15.8^{b}$ & $28.7^{\mathrm{a}}$ & $10.9^{c}$ & $16.2^{\mathrm{bc}}$ & $30.5^{\mathrm{a}}$ & $5.4^{\mathrm{c}}$ & $15.4^{\mathrm{b}}$ & $26.9^{\mathrm{ab}}$ \\
\hline $\begin{array}{l}\text { Mean geometric } \\
\text { diameter }(\mathrm{mm})\end{array}$ & $2.9^{b}$ & $3.6^{\mathrm{a}}$ & $2.7^{\mathrm{b}}$ & $3.0^{\mathrm{b}}$ & $4.1^{\mathrm{a}}$ & $2.9^{b}$ & $2.9^{b}$ & $2.9^{b}$ & $2.4^{\mathrm{b}}$ & $3.1^{\mathrm{b}}$ & $5.4^{\mathrm{a}}$ \\
\hline Sphericity (\%) & $24.8^{\mathrm{a}}$ & $20.8^{\mathrm{a}}$ & $28.2^{\mathrm{a}}$ & $17.6^{\mathrm{b}}$ & $22.7^{\mathrm{ab}}$ & $34.1^{\mathrm{a}}$ & $21.1^{\mathrm{ab}}$ & $19.2^{b}$ & $22.3^{\mathrm{ab}}$ & $14.1^{\mathrm{b}}$ & $26.1^{\mathrm{ab}}$ \\
\hline
\end{tabular}

Means with the same letter in each column are not significantly different according to Duncan Multiple Range Test

IX: Analysis of variance of cultivar and moisture content effects and their interactions on grain and wheat straw terminal velocity

\begin{tabular}{|c|c|c|c|c|c|c|c|}
\hline \multirow{3}{*}{ Sources of variations } & \multirow{3}{*}{ DF } & \multicolumn{6}{|c|}{ Mean of squares } \\
\hline & & \multicolumn{3}{|c|}{ Grain terminal velocity } & \multicolumn{3}{|c|}{ Straw terminal velocity } \\
\hline & & Horizontal & Lateral & Vertical & Horizontal & Lateral & Vertical \\
\hline Cultivar & 1 & $0.009^{\text {ns }}$ & $0.010^{\mathrm{ns}}$ & $0.100^{* *}$ & $0.0005^{\mathrm{ns}}$ & $0.0020^{\mathrm{ns}}$ & $0.159^{* *}$ \\
\hline MCdb. & 1 & $0.64^{* *}$ & $0.28^{* *}$ & $0.63^{* *}$ & $0.008^{\mathrm{ns}}$ & $0.037^{* *}$ & $0.062^{* *}$ \\
\hline Cultivar $\times \mathrm{MC}_{\mathrm{db}}$ & 1 & $0.0007^{\text {ns }}$ & $0.0004^{\text {ns }}$ & $0.004^{\text {ns }}$ & $0.0021^{\text {ns }}$ & $0.00007^{\mathrm{ns}}$ & $0.0012^{\text {ns }}$ \\
\hline Error & 8 & 0.0078 & 0.0050 & 0.0078 & 0.0018 & 0.0028 & 0.0046 \\
\hline
\end{tabular}

ns = non-significant, ${ }^{*}=\mathrm{P} \leq 0.05 ;{ }^{*}=\mathrm{P} \leq 0.01$

thickness and geometric diameter of rachis in Mehr cultivar were 22.4, 2.2 and $5.4 \mathrm{~mm}$, respectively, and the largest width was $5.2 \mathrm{~mm}$ for chaff in Mehr cultivar. The highest weight was for rachis in Cham cultivar with the amount of $30.5 \mathrm{mg}$ and the highest sphericity coefficient with a value of $34 \%$ was for chaff in Cham cultivar.

\section{Terminal Velocity of Grain and Straw}

The results of analysis of variance of terminal velocity in three positions of motion in horizontal, vertical and lateral states are presented in Tab. IX. According to these results, the effect of cultivar on terminal velocity of grain and straw was significant at $1 \%$ probability level only in vertical position which was unstable perfectly, and in other positions, it did not have a significant effect. The effect of $\mathrm{MC}_{\mathrm{db}}$ was significant at $1 \%$ probability level on terminal velocity of grains in all three positions and on straw in vertical and lateral positions. Interaction effects of cultivars and moisture content was not significant on terminal velocity of grain and wheat straw.

According to Tab. X, the maximum and minimum values of grain's terminal velocity were 8.9 and $7.3 \mathrm{~m} / \mathrm{s}$ belonging to Mehr cultivar at $20 \% \mathrm{MC}_{\text {d.b }}$ and Cham cultivar at $14 \% \mathrm{MC}_{\text {d.b. }}$ respectively. Increasing the $\mathrm{MC}_{\mathrm{d} . \mathrm{b}}$, despite the slight effect on increasing the dimensions, leaded to an increase in the terminal velocity, and it can be concluded that increasing particle's weight due to moisture absorption had significant effects on an increase in terminal velocity. The maximum terminal velocity in straw 
X: Comparison of the effect of cultivar and moisture and their interactions on terminal velocity of wheat grain and straw particle

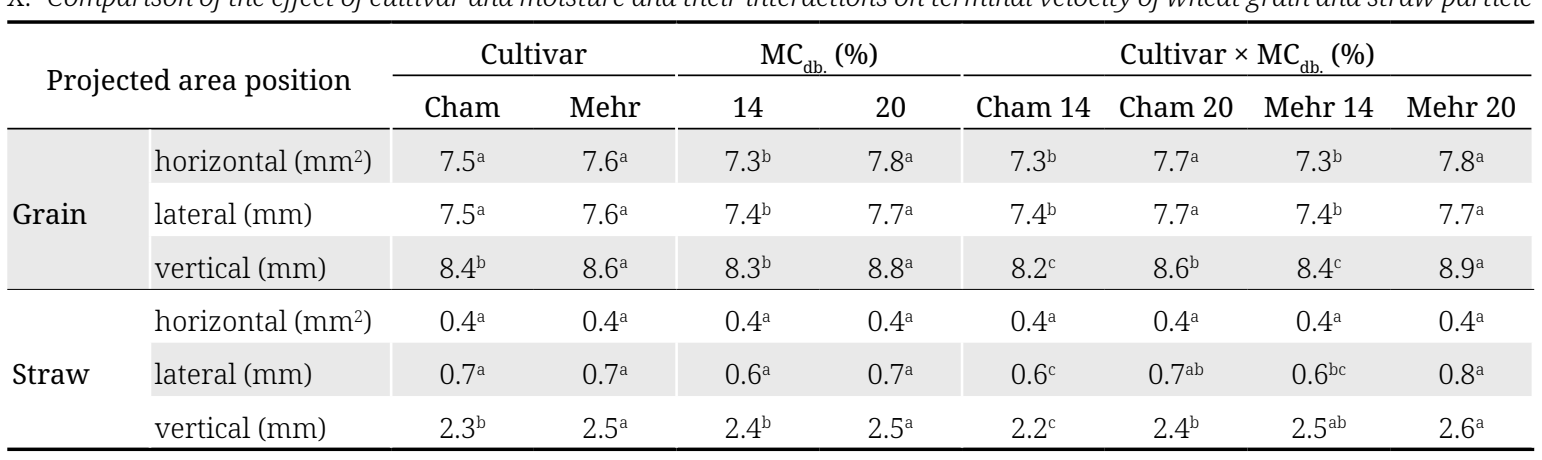

Means with the same letter in each column are not significantly different according to Duncan Multiple Range Test

was in the vertical position and in the range of 2.3 to $2.5 \mathrm{~m} / \mathrm{s}$, and its lowest value was in the horizontal position. The terminal velocity in straw particles at $20 \% \mathrm{MC}_{\text {d.b. }}$ were higher than that in $14 \% \mathrm{MC}_{\text {d.b. }}$ and also were higher in Mehr cultivar compared to Cham. Shahbazi et al. (2014) reported an increase in terminal velocity of wheat grains from 6.3 to $8.0 \mathrm{~m} / \mathrm{s}$ by increasing the $\mathrm{MC}_{\text {d.b. }}$ from 7 to $27 \%$.

\section{CONCLUSION}

Results of this study showed that in general, although both of the studied cultivars had the same weight, their grains had different densities. Generally, the mean dimensions of grain width and straw particles in Mehr cultivar were more than Cham cultivar but had less thickness and weight and thus, they might have different behaviors in the separation systems such as fluid bed and electric field. The shape of the straw and the falling position had different physical and aerodynamic properties, which had direct effects on terminal velocity for the two cultivars. Results of this study can be used in designing wheat- cluster straw separation and processing especially electrostatic separation systems.

\section{REFERENCES}

ASABE. 2006. Moisture measurement, unground grain and seeds. ASAE S352.2 FEB 03. St. Joseph, MI: American Society of Agricultural and Biological Engineers.

BARYEH, E. A. 2002. Physical properties of millet. Journal of Food Engineering, 51(1): 39-46.

GORIAL, B. Y. and O'CALLAGHAN, J. R. 1990. Aerodynamic properties of grain/straw materials. Journal of Agricultural Engineering Research, 46: 275-290.

GUPTA, R. K., ARORA, G. and SHARMA, R. 2007. Aerodynamic properties of sunflower seed (Helianthus annuus L.). Journal of Food Engineering, 79(3): 899-904.

GURSUY, S. and GUZEL, E. 2010. Determination of physical properties of some agricultural grains. Research Journal of Applied Sciences, Engineering and Technology, 2(5): 492-498.

HEMMAT, A., EMAMY, M., RAZAVI, S. J. and MASOUMI, A. A. 2010. Terminal velocity of chopped corn silage and its separate fractions as affected by moisture content. Journal of Agricultural Science and Technology, 9: 15-23.

IRTWANGE, S. V. and IGBEKA, J. C. 2003. Effect of accession and moisture content on aerodynamic properties of African yam bean (Sphenosty lisstenocarpa). Applied engineering in agriculture, 19(3): 321.

ALFONSO JUNIOR, P. C., CORREA, P. C., PINTO, F. A. C. and QUEIROZ, D. M. 2007. Aerodynamic properties of coffee cherries and beans. Biosystems Engineering, 98(1): 39-46.

KALLAN, F. and KARA, M. 2011. Handling, frictional and technological properties of wheat as affected by moisture content and cultivar. Powder Technology, 213(1-3): 116-122.

KHOSHTAGHAZA, M. H. and MEHDIZADEH, R. 2006. Aerodynamic properties of wheat kernel and straw materials. Agricultural Engineering International: CIGR Journal, 8: n. pag.

MOHSENIN, N. N. 1986. Physical Properties of Plant and Animal Materials, $2^{\text {nd }}$ Edition. New York, USA: Gordon \& Breach Science Publishers.

NALBANDI, H., CHASEMZADEH, H. R. and SEIIEDLOU, S. 2010. Seed moisture dependent on physical properties of Turgenia latifolia: criteria for sorting. Journal of Agricultural Technology, 6(1): 1-10.

RABBANI, H. 2002. Aerodynamic properties of chick pea. Dissertation Thesis. Tehran, Iran: University of Tehran. 
RAJABIPOUR, A., TABATABAEEFAR, A. and FARAHANI, M. 2006. Effect of moisture on terminal velocity of wheat varieties. International Journal of Agriculture and Biology, 8(1): 10-13.

SARMADNIA G. 1997. Seed technology. Mashhad, Iran: Jehad-e-Daneshgahi.

SHAHBAZI, F., VALIZADEH, S. and DOWLATSHAH, A. 2014. Aerodynamic properties of Makhobeli, triticale and wheat seeds. International Agrophysics, 28(3): 389-394.

SOLTANI, M., ALIMARDANI, R. and OMID, M. 2011. Use of dielectric properties in quality measurement of agricultural products. Nature and Science, 9(4): 57-61.

TABAK, S. and WOLF, D. 1998. Aerodynamic properties of cottonseeds. Journal of Agricultural Engineering Research, 70(3): 257-265.

TABATABAEEFAR, A. 2003. Moisture-dependent physical properties of wheat. International Agrophysics, 17(4): 207-211.

UNAL, H., ISIK, E. and ALPSOY, H. C. 2006. Some physical and mechanical properties of Black-eyed pea (Vigna Unguiculata L.) grains. Pakistan Journal of Biological Science, 9(9): 1799-1806.

YILDIRIM, A., ONER, M. D. and BAYRAM, M. 2011. Fitting Fick's model to analyze water diffusion into chickpeas during soaking with ultrasound treatment. Journal of Food Engineering, 104(2011): 134142.

ZEWDU, A. D. 2007. Aerodynamic properties of tef grain and straw material. Biosystems engineering, 98(3): 304-309.

Contact information

Mohammad Jafari: mjafari1971@ut.ac.ir Gholam Reza Chegini: chegini@ut.ac.ir Javad Khazaei: jkhazaei@ut.ac.ir 